\title{
Performance of Educational Assessments: Integrated Assessment as an Assessment Innovation during the Covid-19 Pandemic
}

\author{
Kamaludin, \\ Universitas Negeri Semarang, Semarang 50229, Indonesia. kamaludin.abahrizka@students.unnes.ac.id. \\ Joko Widodo, \\ Universitas Negeri Semarang, Semarang 50229, Indonesia.jokowidodo@mail.unnes.ac.id. \\ Eko Handoyo, \\ Universitas Negeri Semarang, Semarang 50229, Indonesia. ekohandoyo@ mail.unnes.ac.id. \\ Ali Masyhar, \\ Universitas Negeri Semarang, Semarang 50229, Indonesia.ali_masyhar@mail.unnes.ac.id.
}

\begin{abstract}
This research aims to find a theoretical concept of assessment for students during the Covid-19 pandemic as a follow-up step for assessment activities in obtaining the validity of assessment results. The research method used is qualitative research methods and conducted on ten Public Elementary School Principals with at least 5 years of teaching experience. The purposive sampling method was used to determine the informants. Here focuses on Analyzing the assessment process and the student learning outcomes process through online learning process during the Covid-19 pandemic. Data collection techniques, in this study, are observation, interviews, and documentation. To obtain data validity, this study uses triangulation of data collection techniques. The result of this study is an integrated assessment theory concept towards the students during the Covid-19 pandemic. The impact of this study provides a new breakthrough, because it provides a different perspective of assessment by integrating 3 perspectives in assessing student academic performance as well as collaborating their own function, namely the teacher's as an assessor of student cognitive competence, the student's as assessors of their own affective competence (self assessment), and the parents' as assessors of students' psychomotor competencies. The further research can be carried out when the Covid-19 pandemic has ended so that it can provide a different view of the effectiveness of using integrated assessment as an assessment method which can be used sustainably in the future
\end{abstract}

Keywords: Performance of educational assessments, Assessment Innovation, Integrated Assessment, Covid-19 Pandemic

\section{INTRODUCTION}

Performance of Educational assessment is a process and work result in gathering information related to student learning outcomes, then processing the information as a basis to decide the learning outcomes that have been carried out by students (Heitink et al., 2016; Rusalam et al., 2019). Performance is a record of the results obtained from certain job functions or certain activities during a certain period of time (Bernardin dan Russel, 1998). In this regard, the educational assessment performance provides an overview of the extent to which the quality of the learning process carried out in schools (Woessmann, 2016). The educational assessments performance must be carried out objectively (Szasz et al., 2017), because it becomes a basis for school principals in determining follow-up steps to policies carried out by teachers (Croft et al., 2019). In determining the performance of educational assessments, the teachers not only face the mechanisms and procedures, but also on the assessment instruments used in measuring student learning outcomes (Birenbaum et al., 2015;Kulasegaram \& Rangachari, 2018).

The current condition with the outbreak of Covid-19 requires an adaptive and innovative attitude for the performance of educational assessment in order to measure the quality of the learning process (Elzainy et al., 2020), and to be able to conform to the current conditions so that school performance can generally be improved. The assessment mechanism should be adaptive and innovative, so that the educational assessments can validly measure the learning process (Birenbaum, 2007). In measuring the quality of the learning process, the role of assessment becomes the most important thing in realizing it (Higgins et al., 2010; Molina et al., 2020). It requires the assessment mechanism adapted with current conditions so that the learning process can be measured validly thus the principals can evaluate the assessments easily (Hopster-den Otter et al., 2017). It is expected the quality of education can be achieved in complying the expectation and need of educational service customer.

Gryna et al suggests that the term customer in educational services is as internal and external customers (Gryna et al., 2007). Learning participants who experience the educational service products directly are the main external customers. Then parents, regional heads, and employers of learning participants are the second external customers. Meanwhile, the labor market, government, and society are the external tertiary customers. Then the 
teaching staff and education staff are internal customers. The potential of non-objective educational assessments during the Covid-19 pandemic is due to the change of learning activities from face-to-face learning to online learning (Carrillo \& Flores, 2020;Patricia Aguilera-Hermida, 2020; Valverde-Berrocoso, del Carmen GarridoArroyo, et al., 2020). The teachers and students need to adapt to the conditions occurred during the Covid-19 pandemic. The non-objective assessment will have an impact on improving the quality of learning therefore the suitability of the assessment mechanism must be considered so that the validity of measuring student learning outcomes can be achieved.

The assessment is focused on the learning process and the assessment process towards student learning outcomes which was carried out online (Adedoyin \& Soykan, 2020;Daniel, 2020;Bozkurt et al., 2020) . Schools and students should prepare the implementation of online learning because it requires supporting devices such as computers or laptops, smart phone, and other tools to connect with internet. Besides that, the ability of teachers and students to operate these tools greatly determines the effectiveness of the implementation of online learning (Tuan Nguyen, 2015; Valverde-Berrocoso et al., 2020; Allen et al., 2020).

In this regard, the principal can find out how far the effectiveness of the online learning process carried out by the teacher through the assessment of learning outcomes. However, the assessment of learning outcomes which is one of the basics for the principals in following up on the development of teacher professional competence and improvement of the quality of learning through supervision activities has not provided the objectivity of the assessment during this pandemic. It is due to the limitation of students in carrying out the online learning process (Arora \& Srinivasan, 2020). This condition will affect on the lack of its maximum absorption of material as well as understanding gained by students. It will also have an impact on students' difficulties in completing the learning assessment instruments provided by the teacher. There needs to be a collaboration between teachers, students and parents. Assessment of learning outcomes is an indicator of the quality of an education (Baartman et al., 2007; Akareem \& Hossain, 2016; Gerritsen-van Leeuwenkamp et al., 2017). In this case, the assessment of learning outcomes needs to obtain quality guarantee through learning supervision. The main function of assessment is to collect data and information on learning outcomes through the provision of valid (precise) and reliable (fixed) assessment instruments (Paolini, 2015; Abdeljaber \& Ahmad, 2017;Anh, 2017). The data and information of the assessment results (evidence) are used by the teacher as feedback to help students improve the quality of their learning and understand the subject matter well. The assessment can be generally categorized as (1) standard assessment, in which question material and administration are prepared and carried out by independent assessment institutions or external parties, (2) assessments conducted by teachers / schools, the subject matter is prepared by the teacher (teacher made test) .

Based on the utilization of the results, the assessment can be classified as formative assessment and summative assessment (Büyükkarc1, 2014;Iannone \& Jones, 2017). Formative assessment is an assessment that is integrated with the learning process, namely the data and information obtained from the assessment results which will be used to help students learn better so that they understand correctly the concepts and material that have been taught according to the learning objectives. In formative assessment, the teacher should not think about grades or numbers or make judgments that students succeed or fail because the learning process is still ongoing. Meanwhile, summative assessment is a decision about the learning outcomes that have been carried out. Data and various information on the results of the assessment (evidence) related to the learning objectives organized will be used to make learning outcomes decisions (assigning grade). How accurately the evidence is can explain the level of achievement of learning objectives and determine the grade of each student. Formative assessment can be carried out after one unit or two of the learning material has been implemented, while summative assessment is carried out after some learning material has been taught. Summative assessments can be carried out at the middle or final semester.

During the Covid-19 pandemic, learning assessment still needs to be done so that teachers know how well learning material has been absorbed by students. It is also as an illustration of the quality level that has been achieved in a learning process. The results of student learning assessments are also an illustration of the followup steps for the learning supervision activities carried out by the principal towards the teachers in order to develop teacher professional competence and improve the quality of learning during the Covid-19 pandemic. On the other hand, the results of the student learning assessment are a description for parents about the academic their children achievements (Wilder, 2014; Hungi \& Mahuro, 2016). Related to the assessment result, the process of students in answering the assessment instrument carried out at home has the potential to be dishonest. It means the students have a chance to cheat, use the Google search engine, and even the exam is done by the their parents. Is the assessment valid? What innovations are needed to respond to such conditions? These questions will be answered in this article. 
This study aims to obtain the concept of assessment theory for students during the Covid-19 pandemic as a further step in obtaining the validity of the learning assessment results.

\section{METHOD}

The method used in this research is qualitative. Qualitative research focuses on interpretation, uses many methods, and has naturalistic measure in approaching the subject matter by studying, understanding, and interpreting existing phenomena (Denzin \& Lincoln, 2005).This research is based on follow-up in obtaining solutions to the invalidity of data obtained by teachers when conducting learning assessments during the Covid19 pandemic. In this research, The main focus is to analyze the assessment process of the online learning and student learning outcomes during the Covid-19 pandemic.

\subsection{Participants}

This research was conducted on ten principals of State Elementary Schools with at least 5 years of teaching experience. It was conducted from September to December 2020. The location was in Brebes Regency, Central Java, Indonesia. The researchers used purposive sampling method to determine the informants. Purposive sampling is a method of selecting non-probability samples through subjective considerations (Forster, 2001). The use of the purposive sampling method is expected to provide valid data from informants who have criteria in accordance with this study, namely the research informants must have commitment and motivation to improve the quality of the learning process. They have an educator certificate and extensive knowledge about the curriculum, lesson plans, learning methods, assessment of learning outcomes, and evaluation of the learning process.

\subsection{Data collection}

In this study, the researchers used observation, interviews, and documentation to collect data. To ensure the validity of the data obtained, they also used triangulation methods by conducting in-depth interviews, observing the research subjects specifically, and conducting literature reviews simultaneously for the same data source. The triangulation method is the use of several methods in a phenomenon research with the aim of reducing refraction from one method (Denzin, 1970).

\subsection{Data analysis}

In this qualitative research, data analysis includes some steps such as organizing data, conceptualizing ideas, building themes, conducting data validity and reliability tests, explaining research findings, and finally drawing research conclusions (O’Connor \& Gibson, 2003).

In conducting data analysis, the researchers chose the main things which supported the achievement of the research objectives. It is presented in a narrative form then the research findings will be presented in the results and discussion section based on valid evidence obtained from the data collection that has been carried out.

\section{RESULT AND DISCUSSION}

The result of this research is an integrated assessment theory concept during the Covid-19 pandemic as a further step in obtaining the validity of the learning assessment results. This integrated assessment is carried out by collaborating the roles of teachers, students, and parents in order to produce the valid assessments related to the students' cognitive, affective, and psychomotor aspects. The teacher's role is related to cognitive aspects through written, oral, and assignment tests. The students play role in conducting self-assessment in the affective aspect by providing self-descriptions in written and oral form. Then the parents' role is by assessing the students' psychomotor aspects related to performance related to learning that has been done at home during the Covid-19 pandemic.

\subsection{Validity of the assessment}

Learning assessment provides an overview of the achievement of the quality of the learning process that has been carried out (Wiliam et al., 2004; Wylie, 2020; Phothongsunan, 2020). Educational assessment is a process to obtain information about student achievement or performance. The results of the assessment are used to evaluate students' learning completeness and the effectiveness of the learning process (Ruiz-Primo et al., 2004; Adom et al., 2020). In this regard, the focus of educational assessment is the learning success of students in achieving the specified competency standards, as well as measuring student achievement in a learning program (Richmond et al., 2019; Sánchez et al., 2020).

There are several basic principles of learning assessment that must be understood by teachers in carrying out the learning assessment process in order to achieve the validity of the assessment results so that they can 
measure the achievement of learning, namely viewing assessment and learning activities are in integrated manner (Preston et al., 2020)(Schildkamp et al., 2020), the use of various assessment strategies in learning programs to provide various types of information about student learning outcomes (Lile \& Bran, 2014), and assessments take into account the various needs of students (Veldhuis \& van den Heuvel-Panhuizen, 2014;Téllez \& Mosqueda, 2015).

\subsection{Integrated assessment as a follow-up step for learning assessment during the Covid-19 pandemic}

In order to maintain the quality of the learning process carried out, a learning process quality assurance is needed through learning assessment activities. The results of the learning assessment provide an overview of the teacher's performance (Fayne, 2007; Noor et al., 2020a). The teacher performance can be assessed against the four activities, namely lesson plan, learning implementation, assessment of student learning outcomes, and learning evaluation. During the Covid-19 pandemic, the assessment of learning outcomes is important in order to find out how effective the learning process for students was carried out by the teacher. The validity of the student learning outcomes assessment will affect the follow-up steps that will be taken by the principal as a learning supervisor through guidance for teachers regarding their professional competence and the quality of the learning process. However, during the Covid-19 pandemic, the assessment do not provide a valid data description due to the low level of learning while studying from home (Abdullah Sharadgah \& Abdulatif Sa'di, 2020; Huber \& Helm, 2020).This will have an impact to the principal in determining the follow-up steps that must be taken in improving the quality of learning process carried out by the teacher.

In implementing the learning assessment process during the Covid-19 pandemic requires collaboration from every school stakeholder (Rusmiati et al., 2020). The Collaboration is needed considering the situation, because the learning process has many obstacles, especially for elementary school students (Putri et al., 2020;Jan, 2020). The limited ability of elementary school students in using digitalization technology makes learning less optimal. The parents' role is needed to be able to accompany, direct, and supervise their children in carrying out the online learning process (Abuhammad, 2020; Lehrl et al., 2020). The process carried out must be able to measure the extent of its success through the implementation of the assessment. However, it is very difficult to carry out a valid assessment during the Covid-19 pandemic (Khan \& Jawaid, 2020; Daniel, 2020a). This is because the learning assessment process during the Covid-19 pandemic must be done at each student's home. Therefore, to get a valid assessment result, It must use an Integrated Assessment.

This integrated assessment is an assessment carried out by collaborating the roles of teachers, students, and parents in order to produce valid assessments for students related to cognitive, affective, and psychomotor. The results of the assessment will be used as the basis for follow-up steps for the principal as the learning supervisor in providing guidance for the development of teacher professional competence and improving the quality of the learning process, such as guidance on appropriate learning strategies or providing remedial or additional lessons for students who are most left behind. The teacher role, in this integrated assessment, includes the preparation of assessment instruments on the cognitive aspects through written, oral, as well as manual or online-based assignments. Furthermore, the students play a role in conducting self-assessment in the affective aspect by providing self-descriptions in written, oral by recording videos. Meanwhile, the parents' role is by conducting psychomotor performance assessments related to the learning that has been done.

The integrated assessment here is an innovative learning assessment during the Covid-19 pandemic. This is important in responding to the condition that makes it impossible to carry out face-to-face comprehensive tests. Thorough assessment related to cognitive, affective, and psychomotor aspects of students can be provided comprehensively through three different perspectives, namely cognitive assessment by teachers, affective assessment by students (self-assessment), and psychomotor assessment by parents. The results of this integrated assessment are accumulated into the final grade of students report. In elementary schools level, It requires the role of teachers and parents in supervising and guiding students so that they can carry out self-assessment objectively. It is because the competence of elementary school students have not been optimal in carrying out self-assessment in the form of self-descriptions.

\subsection{Integrated assessment characteristics, in terms of relative advantage, compatibility, complexity, triability, and observability}

The characteristics of innovation are one of the things that have an effect on the velocity of an innovation process. Rogers (1983) argues that there are five characteristics of innovation, namely relative advantage, compatibility, complexity, triability and observability. In this integrated assessment, these characteristics can be explained as follows: 


\subsubsection{Integrated assessment of Relative Advantage}

Relative Advantage is the level of excess of an innovation, whether it is better than previous innovations or things that are usually done (Abbas et al., 2017; Vagnani \& Volpe, 2017). It is usually measured in terms of economy, social achievement, comfort and satisfaction. The greater the relative advantage felt by the adopter, the faster innovation is adopted (Ismail, 2012). This integrated assessment has a relative advantage in the social and satisfaction aspects because it has three different assessment perspectives for one student compared to the assessments that are only centered on the teacher's perspective in assessing cognitive, affective, and psychomotor competencies.

The advantage, in the social aspect, is clearly visible by considering the current conditions which do not allow face-to-face assessments. While the superiority in satisfaction aspect of can be seen in the students' satisfaction who are given the trust and able to conduct self-assessment on their affective competences through self-descriptions which can be written or oral. In addition, their parents can play an active role in providing an assessment of the student's performance. This will have an impact on increasing parental attention to the learning process carried out by students.

\subsubsection{Integrated assessment of Compatibility}

Compatibility is the suitability level of an innovation, whether it is considered consistent or in accordance with existing values, experiences and needs. If the innovation is opposite or not in accordance with the values and norms held by users, the new innovation cannot be adopted easily by users (Wisdom et al., 2014; Alan et al., 2017). This integrated assessment has a conformity with current values, experiences, and needs. The suitability of these values is related to the integration assessment process which can still measure the achievement of student learning outcomes validly in the conditions of the Covid-19 pandemic in three different collaborative perspectives.

Related to suitability for experience, the integrated assessment will consistently be able to be carried out by teachers, students, and parents based on the experiences they have. We know that teachers are experientially able to assess the cognitive aspects. On the attitude aspects, students have a better understanding than others regarding things that students feel personally. Then in conducting an assessment related to psychomotor aspects, their parents can assess the results of student performance based on their observations about the success or failure of the student's performance.

\subsubsection{Integrated assessment of Complexity}

Complexity is the level of complexity of an innovation to be adopted, how difficult it is to understand and use innovation (Katz, 2016; Ruoslahti, 2020). The easier an innovation is understood by the adopter, the faster the innovation is adopted (Dryden-Palmer et al., 2020). This integrated assessment has low complexity. It is because this integrated assessment is an assessment based on consideration of the scope according to the understanding held by teachers, students, and parents as assessors so that it is easier to understand. In addition, It is carried out with a simple but meaningful concept through collaborative control assessments carried out by the principal. The simple and meaningful concept here mean that integrated assessment is carried out in an effort to measure learning outcomes according to the students and parents ability to provide assessments in the form of qualitative (good / bad) or quantitative (numbers) assessments.

\subsubsection{Integrated assessment of Trialability}

Trialability, can be tested, is the level at which an innovation can be tried first or must be bound to use it (Mannan \& Haleem, 2017; Yoon \& Lim, 2020). An innovation can be tested in real conditions, then innovation is generally adopted more quickly. To accelerate the adoption process, an innovation must be able to show its superiority (Gupta et al., 2016; Lee \& Yoo, 2019). This integrated assessment as a learning assessment innovation during the Covid-19 pandemic is very appropriate to be tested as a solution in addressing the invalidity of the results of learning assessments because they are constrained by conditions that do not allow face-to-face assessment processes in the class.

In this regard, the integrated assessment on the trialability aspect is very possible to produce good responses from teachers, students, and parents. In this case, the teacher is the driving force in directing the implementation of this integrated assessment trial. To measure the aspect of attitude (affective), students can adopt it well because this is directly related to everything that students feel accordance with the actual situation. 
Likewise with the parents, the time and place of the assessment at home will be easier and more objective in doing integrated assessments related to aspects of skills (psychomotor).

\subsubsection{Integrated assessment of Observability}

Observability is the degree to which the results of using an innovation can be seen by others. The easier it is seen to the results of an innovation, the more likely the innovation is adopted by a person or group of people (Scott et al., 2008; Toole et al., 2012; Miranda et al., 2016;Alan et al., 2017). This integrated assessment is an innovation in assessment for students during the Covid-19 pandemic. The use of integrated assessment is very relevant to the current conditions. The validity of the data obtained and good collaboration between teachers, students, and parents of students provide a good view for education stakeholders and society in general about integrated assessment. It becomes a basic assumption for education stakeholders and the community that the use of integrated assessment is very comprehensive in achieving the validity of the assessment results. This integrated assessment also has the potential to be used in the future as an integrated assessment for students from three different perspectives, namely the teacher's perspective on cognitive aspects, students 'perspectives on affective aspects, and parents' perspectives regarding psychomotor aspects.

\subsection{Opinion leader of integrated assessment}

Someone can not immediately trust the information they have just received but they will trust the information when it is submitted by someone they trust (Gächter \& Renner, 2018; Dwivedi et al., 2020). The people are called opinion leaders. Opinion leader functions as an element that influences how the diffusion of innovation poses occurs in the social system. According to Rogers (1983), Opinion leader associated with Diffusion of Innovation is an early adopter who will then be imitated by his followers.

The principal is an opinion leader in integrated assessment. In this case The principal as the school leader has a role to be the first person to practice this integrated assessment as a follow-up step to learning assessment activities carried out during the Covid-19 pandemic. Through the role of the principal as school leader, teachers as school members have confidence about the benefits generated by using integrated assessments in assessing students during the current condition. Besides that, through the authority he has, he can use coercion strategies. Coercive strategies means by forcing clients (change goals) to achieve the change goals and coercive strategies are appropriate if the expected social change must be realized in a short time or the change goals must be achieved immediately (Zaltman \& Duncan, 1977).

Considering the Covid-19 pandemic is an issue that has an impact on the education process (Espino-Díaz et al., 2020; Abidah et al., 2020). So the principal as an opinion leader can implement a coercion strategy so that teachers are willing to accept integrated assessments as an innovation that is very useful as a follow-up to academic supervision activities in order to solve the problem of the validity of assessments for students during the Covid-19 epidemic. In this case, the principal as an opinion leader is in charge of providing close supervision so that the diffusion process of innovation is going well as expected.

\subsection{The speed of social system adoption related to innovation in integrated assessment}

This integrated assessment has a fast adoption rate in the social system. Broadly speaking, this integrated assessment is a development of an assessment based on the current situation related to the Covid-19 pandemic which does not allow face-to-face assessments. This development is the basis for school principals in formulating steps for implementing appropriate innovations as a follow-up step for learning assessments during the Covid-19 pandemic. The speed of adoption of the social system is influenced by the motivation and commitment of the principal and teachers as the driving force. The clarity of the integrated assessment mechanism needs to be emphasized so that teachers, students and parents can carry out their roles and functions in accordance with the direction of the school principal.

The teachers, students, and parents carry out their roles and functions in accordance with the scope of the assessment that is directly related to themselves. The teachers play a role in assessing students' cognitive competencies, where this is their duty and responsibility professionally as an educator to be able to carry out an assessment process for their students. This condition makes the speed of adoption of integrated assessment for teachers to be fast. Furthermore, the students play a role in assessing affective competence, by what students feel directly related to the learning process that has been carried out. In other words, the speed of adopting integrated assessment can be fast, because the students assess themselves regarding their real affective competence. 
The Parents play a role in assessing students' psychomotor competencies. The process of psychomotor assessment is related to performance related to learning carried out by students. During the Covid-19 pandemic which requires the students to study from home and parents' participation to help the implementation of learning to take place effectively (Koskela et al., 2020), on this basis parents' participation is very much needed. In assessing students' psychomotor competence, the parents provide simple but objective assessments either using qualitative assessments related to good / bad performance / practical results or quantitatively through assessments from numbers 1 to 10. The ease of providing this assessment will have an impact on adoption which carried out by parents on the students' psychomotor aspects.

\section{CONCLUSSION}

This research shows that integrated assessment is an innovation in obtaining the validity of assessments for students during the Covid-19 epidemic. It requires commitment and motivation of teachers as collaborators and principals as school leaders so that the assessment is going well in accordance with stakeholder expectations. The assessment can also provide a true picture of the level of student achievement in the learning process carried out through online learning at students' house. This interactive assessment provides a new breakthrough because it provides a different perspective of assessment by integrating three perspectives in assessing student academic performance, namely the teachers' perspective, the students' perspective, and the parents' perspective as well as collaborating the teacher's function as a student's cognitive competency assessor, the student's function as an assessor of his affective competence (self assessment), and the parents as assessors of students' psychomotor competence.

This research was only conducted for the principal of state Elementary Schools in carrying out learning supervision activities on learning assessments related to the online learning process and the process of assessing student learning outcomes so that it has limited analysis on assessments related to online learning and the assessment process of student learning outcomes during the Covid-19 pandemic. Thus, further research can be carried out when the Covid-19 pandemic has ended so that it can provide a different picture of the effectiveness of using integrated assessment as an assessment method that can be used sustainably in the future. A further research can also be carried out in the regions and different countries so it is expected that they can produce findings which are more general.

\section{REFERENCES}

1. Abbas, M., Shahid Nawaz, M., Ahmad, J., \& Ashraf, M. (2017). The effect of innovation and consumer related factors on consumer resistance to innovation. Cogent Business and Management, 4(1). https://doi.org/10.1080/23311975.2017.1312058

2. Abdeljaber, H. A. M., \& Ahmad, S. (2017). Program outcomes assessment method for multi- academic accreditation bodies: Computer science program as a case study. International Journal of Emerging Technologies in Learning, 12(5), 23-35. https://doi.org/10.3991/ijet.v12i05.6410

3. Abdullah Sharadgah, T., \& Abdulatif Sa'di, R. (2020). Preparedness of Institutions of Higher Education for Assessment in Virtual Learning Environments During the COVID-19 Lockdown: Evidence of Bona Fide Challenges and Pragmatic Solutions. Journal of Information Technology Education: Research, 19, 755-774. https://doi.org/10.28945/4615

4. Abidah, A., Hidaayatullaah, H. N., Simamora, R. M., Fehabutar, D., \& Mutakinati, L. (2020). The Impact of Covid-19 to Indonesian Education and Its Relation to the Philosophy of "Merdeka Belajar." Studies in Philosophy of Science and Education, 1(1), 38-49. https://doi.org/10.46627/sipose.v1i1.9

5. Abuhammad, S. (2020). Barriers to distance learning during the COVID-19 outbreak: A qualitative review from parents' perspective. Heliyon, 6(11). https://doi.org/10.1016/j.heliyon.2020.e05482

6. Adedoyin, O. B., \& Soykan, E. (2020). Covid-19 pandemic and online learning: the challenges and opportunities. Interactive Learning Environments, 1-13. https://doi.org/10.1080/10494820.2020.1813180

7. Adom, D., Mensah, J. A., \& Dake, D. A. (2020). Test, measurement, and evaluation: Understanding and use of the concepts in education. International Journal of Evaluation and Research in Education, 9(1), 109-119. https://doi.org/10.11591/ijere.v9i1.20457

8. Akareem, H. S., \& Hossain, S. S. (2016). Determinants of education quality: what makes students' perception different? Open Review of Educational Research, 3(1), 52-67. https://doi.org/10.1080/23265507.2016.1155167

9. Alan, A. K., Kabadayi, E. T., Bakis, S., Can, Y., \& Sekerin, M. C. (2017). Generating and Assessing Consumer's Innovation Adoption through Consumer Innovativeness, Innovation Characteristics and 
Perceived Brand Innovativeness. International Journal of Marketing Studies, 9(6), 68-81. https://doi.org/10.5539/ijms.v9n6p68

10. Allen, J., Rowan, L., \& Singh, P. (2020). Teaching and teacher education in the time of COVID-19. Asia-Pacific Journal of Teacher Education, 48(3), 233-236. https://doi.org/10.1080/1359866X.2020.1752051

11. Anh, N. V. (2017). The Impact of Online Learning Activities on Student Learning Outcome in Blended Learning Course. Journal of Information \& Knowledge Management, 16(04). https://doi.org/10.1142/S021964921750040X

12. Arora, A. K., \& Srinivasan, R. (2020). Impact of pandemic covid-19 on the teaching - learning process: A study of higher education teachers. Prabandhan: Indian Journal of Management, 13(4), 43-56. https://doi.org/10.17010/pijom/2020/v13i4/151825

13. Baartman, L. K. J., Bastiaens, T. J., Kirschner, P. A., \& van der Vleuten, C. P. M. (2007). Evaluating assessment quality in competence-based education: A qualitative comparison of two frameworks. Educational Research Review, 2(2), 114-129. https://doi.org/10.1016/j.edurev.2007.06.001

14. Bernardin dan Russel. (1998). Human Resource Management: An Experiental Approach. Mc GrawHill, Inc.

15. Birenbaum, M. (2007). Evaluating the Assessment: Sources of Evidence for Quality Assurance. Studies in Educational Evaluation, 33(1), 29-49. https://doi.org/10.1016/j.stueduc.2007.01.004

16. Birenbaum, M., DeLuca, C., Earl, L., Heritage, M., Klenowski, V., Looney, A., Smith, K., Timperley, H., Volante, L., \& Wyatt-Smith, C. (2015). International trends in the implementation of assessment for learning: Implications for policy and practice. Policy Futures in Education, 13(1), 117-140. https://doi.org/10.1177/1478210314566733

17. Bozkurt, A., Jung, I., Xiao, J., Vladimirschi, V., Schuwer, R., Egorov, G., Lambert, S., Al-Freih, M., Pete, J., Olcott Jr., D., Rodes, V., Aranciaga, I., Bali, M., Alvarez Jr., A., Roberts, J., Pazurek, A., Raffaghelli, J., Panagiotou, N., de Coëtlogon, P., ... Paskevicius, M. (2020). A global outlook to the interruption of education due to COVID-19 Pandemic: Navigating in a time of uncertainty and crisis. Asian Journal of Distance Education, 15(1), 1-126. https://doi.org/10.5281/zenodo.3878572

18. Büyükkarc1, K. (2014). Assessment Beliefs and Practices of Language Teachers in Primary Education. International Journal of Instruction, $7(1), \quad 107-120$. http://login.ezproxy.lib.umn.edu/login?url=http://search.ebscohost.com/login.aspx?direct=true\&AuthTy pe $=$ ip,uid $\& d b=$ eue $\& A N=93432958 \&$ site $=$ ehost-live

19. Carrillo, C., \& Flores, M. A. (2020). COVID-19 and teacher education: a literature review of online teaching and learning practices. European Journal of Teacher Education, 43(4), 466-487. https://doi.org/10.1080/02619768.2020.1821184

20. Croft, H., Gilligan, C., Rasiah, R., Levett-Jones, T., \& Schneider, J. (2019). Current Trends and Opportunities for Competency Assessment in Pharmacy Education-A Literature Review. Pharmacy, 7(2), 67. https://doi.org/10.3390/pharmacy7020067

21. Daniel, S. J. (2020a). Education and the COVID-19 pandemic. Prospects, 49(1-2), 91-96. https://doi.org/10.1007/s11125-020-09464-3

22. Daniel, S. J. (2020b). Education and the COVID-19 pandemic. PROSPECTS, 49(1-2), 91-96. https://doi.org/10.1007/s11125-020-09464-3

23. Denzin, N. K. (1970). The Research Act: A Theoretical Introduction to Sociological Methods. Aldine Publishing.

24. Denzin, N. K., \& Lincoln, Y. S. (2005). Introduction. The discipline and practice of qualitative research. SAGE Publications Ltd.

25. Dryden-Palmer, K. D., Parshuram, C. S., \& Berta, W. B. (2020). Context, complexity and process in the implementation of evidence-based innovation: A realist informed review. BMC Health Services Research, 20(1), 1-15. https://doi.org/10.1186/s12913-020-4935-y

26. Dwivedi, Y. K., Ismagilova, E., Hughes, D. L., Carlson, J., Filieri, R., Jacobson, J., Jain, V., Karjaluoto, H., Kefi, H., Krishen, A. S., Kumar, V., Rahman, M. M., Raman, R., Rauschnabel, P. A., Rowley, J., Salo, J., Tran, G. A., \& Wang, Y. (2020). Setting the future of digital and social media marketing research: Perspectives and research propositions. International Journal of Information Management, 137. https://doi.org/10.1016/j.ijinfomgt.2020.102168

27. Elzainy, A., El Sadik, A., \& Al Abdulmonem, W. (2020). Experience of e-learning and online assessment during the COVID-19 pandemic at the College of Medicine, Qassim University. Journal of Taibah University Medical Sciences, 15(6), 456-462. https://doi.org/10.1016/j.jtumed.2020.09.005

28. Espino-Díaz, L., Fernandez-Caminero, G., Hernandez-Lloret, C. M., Gonzalez-Gonzalez, H., \& Alvarez-Castillo, J. L. (2020). Analyzing the impact of COVID-19 on education professionals. Toward 
a paradigm shift: ICT and neuroeducation as a binomial of action. Sustainability (Switzerland), 12(14), 1-10. https://doi.org/10.3390/su12145646

29. Fayne, H. R. (2007). Supervision from the Student Teacher's Perspective: An Institutional Case Study. Studying Teacher Education, 3(1), 53-66. https://doi.org/10.1080/17425960701284016

30. Forster, J. J. (2001). Sample Surveys: Nonprobability Sampling. International Encyclopedia of the Social \& Behavioral Sciences.

31. Gächter, S., \& Renner, E. (2018). Leaders as role models and 'belief managers' in social dilemmas. Journal of Economic Behavior and Organization, 154, 321-334. https://doi.org/10.1016/j.jebo.2018.08.001

32. Gerritsen-van Leeuwenkamp, K. J., Joosten-ten Brinke, D., \& Kester, L. (2017). Assessment quality in tertiary education: An integrative literature review. Studies in Educational Evaluation, 55, 94-116. https://doi.org/10.1016/j.stueduc.2017.08.001

33. Gryna, F., Chua, R., \& DeFeo, J. (2007). Juran's Quality Planning and Analysis. McGraw-Hill Companies.

34. Gupta, S., Malhotra, N. K., Czinkota, M., \& Foroudi, P. (2016). Marketing innovation: A consequence of competitiveness. Journal of Business Research, 69(12), 5671-5681. https://doi.org/10.1016/j.jbusres.2016.02.042

35. Heitink, M. C., Van der Kleij, F. M., Veldkamp, B. P., Schildkamp, K., \& Kippers, W. B. (2016). A systematic review of prerequisites for implementing assessment for learning in classroom practice. Educational Research Review, 17, 50-62. https://doi.org/10.1016/j.edurev.2015.12.002

36. Higgins, M., Grant, F., \& Thompson, P. (2010). Formative Assessment: Balancing Educational Effectiveness and Resource Efficiency. Journal for Education in the Built Environment, 5(2), 4-24. https://doi.org/10.11120/jebe.2010.05020004

37. Hopster-den Otter, D., Wools, S., Eggen, T. J. H. M., \& Veldkamp, B. P. (2017). Formative use of test results: A user's perspective. Studies in Educational Evaluation, 52, 12-23. https://doi.org/10.1016/j.stueduc.2016.11.002

38. Huber, S. G., \& Helm, C. (2020). COVID-19 and schooling: evaluation, assessment and accountability in times of crises - reacting quickly to explore key issues for policy, practice and research with the school barometer. Educational Assessment, Evaluation and Accountability, 32(2), 237-270. https://doi.org/10.1007/s11092-020-09322-y

39. Hungi, N., \& Mahuro, G. M. (2016). Parental participation improves student academic achievement: A case of Iganga and Mayuge districts in Uganda. Cogent Education, 3(1), 8-10.

40. Iannone, P., \& Jones, I. (2017). Special issue on summative assessment. Research in Mathematics Education, 19(2), 103-107. https://doi.org/10.1080/14794802.2017.1334578

41. Ismail, A. R. (2012). Understanding the Factors That Affect the Adoption of Innovative HighTechnology Brands: The Case of Apple iPhone in Malaysia. Journal of Global Marketing, 25(4), 226239. https://doi.org/10.1080/08911762.2012.753564

42. Jan, A. (2020). A phenomenological study of synchronous teaching during COVID-19: A case of an international school in Malaysia. Social Sciences \& Humanities Open, 2(1), 100084. https://doi.org/10.1016/j.ssaho.2020.100084

43. Katz, J. S. (2016). What Is a Complex Innovation System? PLOS ONE, 11(6). https://doi.org/10.1371/journal.pone.0156150

44. Khan, R., \& Jawaid, M. (2020). Technology Enhanced Assessment (TEA) in COVID 19 Pandemic. Pakistan Journal of Medical Sciences, 36(COVID19-S4), S108-S110. https://doi.org/10.12669/pjms.36.COVID19-S4.2795

45. Koskela, T., Pihlainen, K., Piispa-Hakala, S., Vornanen, R., \& Hämäläinen, J. (2020). Parents’ views on family resiliency in sustainable remote schooling during the COVID-19 outbreak in Finland. Sustainability (Switzerland), 12(21), 1-20. https://doi.org/10.3390/su12218844

46. Kulasegaram, K., \& Rangachari, P. K. (2018). Beyond "formative": Assessments to enrich student learning. Advances in Physiology Education, 42(1), 5-14. https://doi.org/10.1152/advan.00122.2017

47. Lee, K., \& Yoo, J. (2019). How does open innovation lead competitive advantage? A dynamic capability view perspective. PLOS ONE, 14(11). https://doi.org/10.1371/journal.pone.0223405

48. Lehrl, S., Evangelou, M., \& Sammons, P. (2020). The home learning environment and its role in shaping children's educational development. School Effectiveness and School Improvement, 31(1), 1-6. https://doi.org/10.1080/09243453.2020.1693487

49. Lile, R., \& Bran, C. (2014). The Assessment of Learning Outcomes. Procedia - Social and Behavioral Sciences, 163, 125-131. https://doi.org/10.1016/j.sbspro.2014.12.297 
50. Mannan, B., \& Haleem, A. (2017). Understanding major dimensions and determinants that help in diffusion \& adoption of product innovation: using AHP approach. Journal of Global Entrepreneurship Research, 7(1), 1-24. https://doi.org/10.1186/s40497-017-0072-4

51. Miranda, M. Q., Farias, J. S., de Araújo Schwartz, C., \& de Almeida, J. P. L. (2016). Technology adoption in diffusion of innovations perspective: introduction of an ERP system in a non-profit organization. RAI Revista de Administração e Inovação, 13(1), 48-57. https://doi.org/10.1016/j.rai.2016.02.002

52. Molina, E., Fatima, S. F., Ho, A. D., Melo, C., Wilichowski, T. M., \& Pushparatnam, A. (2020). Measuring the quality of teaching practices in primary schools: Assessing the validity of the Teach observation tool in Punjab, Pakistan. Teaching and Teacher Education, 96. https://doi.org/10.1016/j.tate.2020.103171

53. Noor, I. H., Herlinawati, \& Sofyaningrum, E. (2020). The Academic Supervision of the School Principal: A Case in Indonesia. Journal of Educational and Social Research, 10(4), 81-93. https://doi.org/10.36941/jesr-2020-0067

54. O'Connor, H., \& Gibson, N. (2003). TheQualityoftheInterviewA step-by-step guide to qualitative data analysis. A Journal of Aboriginal and Indigenous Community Health, 1(1), 64-90. https://www.researchgate.net/publication/292432218\%0Ahttp://www.pimatisiwin.com/uploads/128956 6991.pdf

55. Paolini, A. (2015). Enhancing Teaching Effectiveness and Student Learning Outcomes. The Journal of Effective Teaching, 15(1), 20-33.

56. Patricia Aguilera-Hermida, A. (2020). College students' use and acceptance of emergency online learning due to COVID-19. International Journal of Educational Research Open, 1. https://doi.org/10.1016/j.ijedro.2020.100011

57. Phothongsunan, S. (2020). Student and teacher engagement in Learning and assessment with portfolios. Cypriot Journal of Educational Sciences, 15(6), 1569-1573. https://doi.org/10.18844/CJES.V15I6.5317

58. Preston, R., Gratani, M., Owens, K., Roche, P., Zimanyi, M., \& Malau-Aduli, B. (2020). Exploring the Impact of Assessment on Medical Students' Learning. Assessment and Evaluation in Higher Education, 45(1), 109-124. https://doi.org/10.1080/02602938.2019.1614145

59. Putri, R. S., Purwanto, A., Pramono, R., Asbari, M., Wijayanti, L. M., \& Hyun, C. C. (2020). Impact of the COVID-19 pandemic on online home learning: An explorative study of primary schools in Indonesia. International Journal of Advanced Science and Technology, 29(5), 4809-4818.

60. Richmond, G., Salazar, M. del C., \& Jones, N. (2019). Assessment and the Future of Teacher Education. Journal of Teacher Education, 70(2), 86-89. https://doi.org/10.1177/0022487118824331

61. Rogers, E. M. (1983). Diffusion of Innovations. The Free Press.

62. Ruiz-Primo, M. A., Li, M., Ayala, C., \& Shavelson, R. F. (2004). Evaluating students' science notebooks as an assessment tool. International Journal of Science Education, 26(12), 1477-1506. https://doi.org/10.1080/0950069042000177299

63. Ruoslahti, H. (2020). Complexity in project co-creation of knowledge for innovation. Journal of Innovation and Knowledge, 5(4), 228-235. https://doi.org/10.1016/j.jik.2019.12.004

64. Rusalam, N. R., Munawar, W., \& Hardikusumah, I. (2019). Development of Authentic Assessment in TVET. Proceedings of the 5th UPI International Conference on Technical and Vocational Education and Training (ICTVET 2018), 343-349. https://doi.org/10.2991/ictvet-18.2019.78

65. Rusmiati, A. R., Reza, R., Achmad, S., Syaodih, E., Nurtanto, M., Sultan, A., Riana, A., \& Tambunan, S. (2020). The perceptions of primary school teachers of online learning during the COVID-19 pandemic period : A Case study in Indonesia. Journal of Ethnic and Cultural Studies, 7(2), 90-109.

66. Sánchez, T., Gilar-Corbi, R., Castejón, J. L., Vidal, J., \& León, J. (2020). Students' Evaluation of Teaching and Their Academic Achievement in a Higher Education Institution of Ecuador. Frontiers in Psychology, 11, 1-10. https://doi.org/10.3389/fpsyg.2020.00233

67. Schildkamp, K., van der Kleij, F. M., Heitink, M. C., Kippers, W. B., \& Veldkamp, B. P. (2020). Formative assessment: A systematic review of critical teacher prerequisites for classroom practice. International Journal of Educational Research, 103, 1-16. https://doi.org/10.1016/j.ijer.2020.101602

68. Scott, S. D., Plotnikoff, R. C., Karunamuni, N., Bize, R., \& Rodgers, W. (2008). Factors influencing the adoption of an innovation: An examination of the uptake of the Canadian Heart Health Kit (HHK). Implementation Science, 3(1), 1-8. https://doi.org/10.1186/1748-5908-3-41

69. Szasz, P., Louridas, M., Harris, K. A., \& Grantcharov, T. P. (2017). Strategies for increasing the feasibility of performance assessments during competency-based education: Subjective and objective evaluations correlate in the operating room. American Journal of Surgery, 214(2), 365-372. https://doi.org/10.1016/j.amjsurg.2016.07.017 
70. Téllez, K., \& Mosqueda, E. (2015). Teacher Assessment and the Assessment of Students With Diverse Learning Needs. Review of Research in Education, 39(1), 87-121.

71. Toole, J. L., Cha, M., \& González, M. C. (2012). Modeling the Adoption of Innovations in the Presence of Geographic and Media Influences. PLOS ONES, 7(1). https://doi.org/10.1371/journal.pone.0029528

72. Tuan Nguyen. (2015). The Effectiveness of Online Learning: Beyond No Significant Difference and Future Horizons. Merlot Journal of Online Learning and Teaching, 11(2), 309-319. http://jolt.merlot.org/Vol11no2/Nguyen_0615.pdf

73. Vagnani, G., \& Volpe, L. (2017). Innovation attributes and managers' decisions about the adoption of innovations in organizations: A meta-analytical review. International Journal of Innovation Studies, 1(2), 107-133. https://doi.org/10.1016/j.ijis.2017.10.001

74. Valverde-Berrocoso, J., del Carmen Garrido-Arroyo, M., Burgos-Videla, C., \& Morales-Cevallos, M. B. (2020). Trends in educational research about e-Learning: A systematic literature review (2009-2018). Sustainability (Switzerland), 12(12), 1-23. https://doi.org/10.3390/su12125153

75. Valverde-Berrocoso, J., Garrido-Arroyo, M. del C., Burgos-Videla, C., \& Morales-Cevallos, M. B. (2020). Trends in Educational Research about e-Learning: A Systematic Literature Review (20092018). Sustainability, 12(12), 1-23. https://doi.org/10.3390/su12125153

76. Veldhuis, M., \& van den Heuvel-Panhuizen, M. (2014). Primary School Teachers' Assessment Profiles in Mathematics Education. PLoS ONE, 9(1), 1-11. https://doi.org/10.1371/journal.pone.0086817.t008

77. Wilder, S. (2014). Effects of parental involvement on academic achievement: A meta-synthesis. Educational Review, 66(3), 377-397. https://doi.org/10.1080/00131911.2013.780009

78. Wiliam, D., Lee, C., Harrison, C., \& Black, P. (2004). Teachers developing assessment for learning: Impact on student achievement. Assessment in Education: Principles, Policy and Practice, 11(1), 4965. https://doi.org/10.1080/0969594042000208994

79. Wisdom, J. P., Chor, K. H. B., Hoagwood, K. E., \& Horwitz, S. M. (2014). Innovation adoption: A review of theories and constructs. Administration and Policy in Mental Health, 41(4), 480-502. https://doi.org/10.1007/s10488-013-0486-4

80. Woessmann, L. (2016). The importance of school systems: Evidence from international differences in student achievement. Journal of Economic Perspectives, 30(3), 3-31. https://doi.org/10.1257/jep.30.3.3

81. Wylie, E. C. (2020). Observing Formative Assessment Practice: Learning Lessons Through Validation. Educational Assessment, 25(4), 251-258. https://doi.org/10.1080/10627197.2020.1766955

82. Yoon, C., \& Lim, D. (2020). An empirical study on factors affecting customers' acceptance of internetonly banks in Korea. Cogent Business and Management, 7(1), 1-23. https://doi.org/10.1080/23311975.2020.1792259

83. Zaltman, G., \& Duncan, R. (1977). Strategies for planned change. Wiley. 